\title{
INTEGRÁLT VÁROSFEJLESZTÉSI STRATÉGIA: A VÁROSFEJLESZTÉS MEGÚJÍTÁSA ${ }^{1}$
}

\author{
(Integrated Urban Development Strategy: \\ Renewal of the Urban Development)
}

\author{
BARTA GYÖRGYI
}

Kulcsszavak:

integrált városfejlesztési stratégia (IVS) Lipcsei Charta baukultur közösségi részvétel irányitás (governance)

A Lipcsei Charta üj szellemiségú uárosfejlesztési gondolkodást igyekszik meghonositani az integrált városfejlesztési stratégia megfogalmazásával, amelynek lényege a gazdasági, társadalmi és területi szempontok együttes kezelése, a különbözö területi és időbeli szintek összekapcsolása, a helyi szereplök bevonása a tervezés folyamatába, valamint a finanszirozás többcsatomás megoldása. Az IVS eröfeszitéseket követel a myugateurópai országoktól, városoktól is elsösorban a tervezési folyamat demokratizálásában, viszont gyökeresen új korszakot nyit az ujjonnan csatlakozott, volt szocialista tagországokban. Annak ellenére, hogy Magyarorszógon már elkészült majd másfélszáz IVS az elmúlt évben, az az általános hazai vélemény, hogy a városfejlesztés megủjulása - küllönbözö okok miatt - még várat magára. A nemzetközi kipróbált módszerek megismerése és átvétele is segithet ebben a hosszú és nehéz folyamatban.

\section{Bevezetés}

Az Európai Unióban több mint egy évtizedes vita, készülödés után vált elfogadottá az integrált városfejlesztési stratégia, nálunk kampányszerüen robbant be az IVS. A Lipcsei Chartát a fenntartható európai városokról 2007 májusában fogalmazták meg, a végrehajtásáról éppen egy évvel később, az EU szlovéniai elnöksége idején született dokumentum. A magyar kézikönyv - amely a 2007 és 2013 közötti városrehabilitációban részt vevố városok számára készült - 2007 októberében jelent meg. De már ekkor meghirdették nálunk az IVS pályázatokat is, 2008 kora nyári beadási határidővel. Mi több, közel másfélszáz IVS el is készült azóta (Pre-Regeneration... 2005; Egységes tervezési... 2006; Kézikönyv... 2007; Vảrosfejlesztési kézikönyv 2009).

Rendkívül gyorsan peregtek tehát az események, pedig a Lipcsei Charta nem apró technikai változtatásokat javasolt, hanem egy alapjaiban új szellemiségủ városfejlesztési gondolkodást kívánt elindítani az integrált városfejlesztési stratégia (IVS) megfogalmazásával. Ennek lényege a gazdasági, társadalmi és környezeti problémák együttes kezelése, a különbözô területi és időbeli szintek (az akcióterületek, városrészek és a város egészének, valamint a város régiójával való kapcsolatának, illetve múltjának, jelenének és a jövöjének) összekapcsolása, a lakosság és a helyi szereplök bevonása a tervezés folyamatába, valamint a többcsatornás finanszírozás 
Barta Györgyi: Integrált városfejlesztési stratégia: a városfejlesztés megújitása.

Tér és Társadalom, 23. 2009. 3. 1-12. p.

megoldása. Ebben a gondolatmenetben a várostervezés és a tervek megvalósítása alapvetően helyi kezdeményezésü folyamat.

Magyarországon, ahol a terület- és városfejlesztés ez idáig a központi kormányzat akaratának helyi szintre való lebontását jelentette, a Lipcsében meghirdetett integrált városfejlesztési stratégia alapvetően új irány, új korszak kezdete lehet, amely nálunk gyökeresen új gondolkodásmódot követel. A szemlélet átalakulása érthetően igen lassú folyamat, az EU és a magyar kormányzat viszont gyors eredményeket vár. Ezért a gondolkodási, tervezési, végrehajtási folyamatokat fel kell gyorsítani. Ennek érdekében az EU kezdeményezésére és támogatásával a központi kormányzat igyekszik gyökeret verni az új gondolkodásnak, és „top down” eszközökkel próbálja bevezetni az integrált városfejlesztési stratégiát a magyar városfejlesztésben. Vajon lehet-e így jelentôs és gyors eredményt elérni? Vajon sikerül-e belátható időn belül a fejéről a talpára fordítani a városfejlesztési gyakorlatot, elindítani egy többnyire helyi önkormányzati szervezésủ és kezdeményezésű folyamatot?

Szakmai és civil fórumok ${ }^{2}$ foglalkoznak ma is az IVS-sel, nem csak a készitésének, módszereinek problémáival, hanem az integrált városfejlesztés eddigi eredményeivel, vagy éppen eredménytelenségével. (Érdemes rákattintani az Internetre, milliós nagyságrendủ az IVS-sel foglalkozó találatok száma.) A vitatkozók többsége (várostervezők, városvezetők) elfogadja, hogy az integrált gondolkodás jó irány a városfejlesztésben (és nem egy új, értelmetlen teher az önkormányzatok számára), de mégis az az általános vélemény, hogy az IVS nincs (még) a helyén. Egyelöre kétségtelen, hogy egyrészt az IVS-ek sok esetben felszínes, átgondolatlan, hiányos és nem koherens anyagok, amelyek nem mutatják be meggyőzően a város valódi problémáit és lehetőségeit. Másrészt, jóformán, mint pályázati mellékletek jelennek meg, amelyek az akcióterületeken megvalósítandó városközpont megújítás, vagy a szociális rehabilitációt célzó projekttámogatás megszerzésének formális feltételei. Szó sincs tehát egyelöre a városfejlesztés új szellemiségéről.

Nem kétséges, hogy az IVS készítés csak éppen megindított egy új folyamatot, amely valószínüleg leáll, ha nem kap külső és belső késztetést a folytatásra. De hogyan tovább? Van-e további ösztönzés a kormányzat részéról az IVS-ek megújitására, karbantartására, kommunikálására? És megértették-e az önkormányzatok, hogy új feladataik vannak a városfejlesztésben, amit rajtuk kívül más nem fog elvégezni? Mindezt különösen fontos most hangsúlyozni, hiszen 2013-tól ${ }^{3}$ még nehezebb lesz forrásokat találni a városfejlesztés finanszírozására, mivel lezárul az e célra most nagyvonalúan felajánlott vissza nem térítendő uniós támogatás.

Most kell tehát megragadni az alkalmat, felkészülni a nehezebb időszakokra. Ehhez nyújt segítséget a külföldi jó gyakorlatok (best practices) megismerése. Földi Zsuzsa, illetve Czirfusz Márton által írt, a Tér és Társadalom jelen számában megjelenő két tanulmány brit, holland és német tapasztalatokat mutat be. A külföldi megoldások már nem csak a tervezési folyamatra vonatkoznak természetesen, hanem a megvalósítás egyes elemeire is, hiszen az integrált gondolkodás és a fenntarthatóság szempontjai régóta és sokkal inkább áthatják a nyugat-európai várostervezést és fejlesztést. 
Barta Györgyi: Integrált városfejlesztési stratégia: a városfejlesztés megújitása.

Tér és Társadalom, 23. 2009. 3. 1-12. p.

TÉT XXIII. évf. 2009 『 3

Integrált városfejlesztési stratégia ...

\section{Az IVS az Európai Unió városfejlesztö politikája}

Az európai integráció kezdeti szakaszában, az 1970-es évekig, nem foglalkoztak a közös regionális politika kialakításával, részben azért, mert az akkori tagállamok gazdasági fejlettsége közel hasonló volt, és az általános fellendülés szakaszában remélték az országon belüli különbségek kiegyenlíthetöségét a nemzeti regionális politikák segítségével.

Később azonban az integrációban részt vevô országok számának gyarapodásával jelentősen megnövekedtek a területi különbségek is. Az Európai Unió kezdetben kifejezetten a regionális fejlesztésre koncentrált. Ez ahhoz a szemlélethez volt köthető, amely a régióknak a korábbiaknál lényegesen fontosabb szerepet szánt, halványítani szándékozva a nemzetállamok jelentőségét. A célul kitűzött területi különbségek csökkentését a régiók szintjén látták leginkább megoldhatónak. A városfejlesztés e szempontból háttérbe szorult, mivel a fejlett, stagnáló vagy elmaradott térségekben a városok (természetesen különböző mértékben) nagyobb gazdasági dinamikát mutattak a környezetüknél, a gazdasági fejlődés csomópontjai voltak.

Az 1970-es évek közepétől elinduló radikális társadalmi-gazdasági átalakulás Európában elmélyítette a városfejlődés egyenlötlenségeit: miközben a városok a gazdasági fejlődés dinamikahordozói voltak, egyre elviselhetetlenebb strukturális problémákkal küszködtek - társadalmi, gazdasági és környezeti szempontból egyaránt. Így az EU politikájában az 1990-es évek közepétől kezdtek foglalkozni a különböző célú, súlyú és irányultságú városfejlesztési programokkal (1994-ben hirdették meg először az URBAN programokat, amelyek 2006-ig folytatódtak; a városok nehézségekkel küszködő térségeinek rehabilitációja érdekében hozták létre az URBACT programot 2003-ban; az EUKN a városfejlesztéssel kapcsolatos információs rendszer kiépítését túzte ki célul 2004-ben). Jól látható, hogy az EU regionális politikájának középpontjába egyre inkább a város került. A célok között szerepelt a városok közötti kooperáció megerősítése (a többközpontú városrendszerek), a dinamikus és versenyképes városok megteremtése, a városi szerkezet megújitása (területhasználat, infrastruktúrafejlesztés, a szociális problémák kezelése, a városi ökorendszerek stb.), a város és vidéke közötti új partnerség, valamint a vidéki térségfejlesztés.

\section{A városok fenntartható fejlesztése}

A Dániában (Aalborg) 1994-ben megrendezett konferencián fogalmazták meg az európai kis- és nagyvárosok fenntarthatóságáról szóló nyilatkozatot (Aalborg Charta, 1994), amely összefoglalta a városfejlesztés új céljait, és kijelölte a célok megvalósításához szükséges erőfeszítéseket (From Charter... 2004).

- Az európai népesség $80 \%$-a él városokban, a városok a gazdaság központjai. A városok a változó életmód, termelés, fogyasztás kulcsszereplöi.

- Az emberiségnek törekednie kell a társadalmi igazságosság, a fenntartható gazdaság és a környezeti fenntarthatóság elérésére. A város az az alapegység, 
Barta Györgyi: Integrált városfejlesztési stratégia: a városfejlesztés megújitása.

Tér és Társadalom, 23. 2009. 3. 1-12. p.

amely képes a társadalmi, gazdasági és környezeti egyensúlytalanságok kezelésére. Helyi stratégiákat kell kialakítani e problémák megoldására oly módon, hogy a problémáikat ne exportálják a szomszédos vagy más térségekbe.

- A fenntarthatóság elérése kreatív, helyi és egyensúlyt kereső folyamat.

- A városban müködő gazdaság növekedésének határt szab a természeti és fizikai tőke, amelynek kímélését segíti a hatékony felhasználás és az újrahasznosítás.

- Törekedni kell a városi társadalmak fenntarthatóságára, vagyis a társadalmi különbségek csökkentésére az alapvető társadalmi szükségletek elérhetőségével.

- A városfejlesztés fontos célja a területhasználat és a városi mobilitás fenntarthatósága (a magas népsủrủség előnyeinek kihasználása oly módon, hogy az ne sértse a város élhetöségét).

- A városfejlesztésnek érzékenyen kell reagálnia a klímaváltozás kihívásaira (elsősorban az új épületek energiafelhasználásának csökkentésével).

- A helyi önkormányzatoknak kell átszervezni városaikat a fenntarthatóság érdekében. Ebbe a munkába be kell vonni a helyi közösségeket és a gazdasági szereplöket.

- Minden eszközt és intézményt igénybe kell venni e politika megvalósítása érdekében (From Charter... 2004).

$\mathrm{Az}$ Aalborg Charta a városfejlesztésre helyezte a hangsúlyt, állítva, hogy a város önmagát szervezni képes alapegység, amelynek kezelnie kell a városban kialakult társadalmi, gazdasági és környezeti egyensúlytalanságot.

Az Aalborg Chartában már felsorolták azokat az elemeket, amelyeket később az IVS-ek is tartalmaztak: a helyzetértékelést és a jövőkép kialakítását, az alternatív stratégiai lehetőségek értékelését, a célok közötti prioritások meghatározását, a várható eredmények mérhetőségét, a tervek végrehajtásának programozását (határidőkkel és a munkamegosztás kialakításával), a monitoring és a beszámolás folyamatait a terv végrehajtásáról, valamint a kommunikáció és a társadalmi részvétel fontosságát.

\section{A Lipcsei Charta (2007. május) a fenntartható európai városokról}

E dokumentum legfontosabb javaslata az integrált városfejlesztési politika szükséges bevezetésére vonatkozik. A Lipcsei Charta fontos konferenciák, dokumentumok megállapításaira épült ${ }^{4}$ (European Common... 2003; Brenner 2007; Integrated... 2007; Public Hearing... 2007).

- Az EU azt ajánlja, hogy az európai városok a város egészére dolgozzanak ki városfejlesztési programot.

- A városfejlesztési politikát továbbra is nemzeti szinten kell meghatározni, de a megoldásokat a különböző (regionális és helyi) szinteken is keresni kell.

- Együttmüködésre és összekapcsolódásra van szükség a helyi-regionális szintek között. 
Barta Györgyi: Integrált városfejlesztési stratégia: a városfejlesztés megújitása.

Tér és Társadalom, 23. 2009. 3. 1-12. p.

- A helyzetértékelést SWOT elemzéssel kell kiegészíteni.

- Az IVS-eknek tartalmazniuk kell a célok és a jövőkép konzisztens rendszerét, a városrészek ágazati fejlesztésének mủszaki terveit, a vegyes finanszírozás (állami és magán) lehetőségeit, a helyi szereplők és a lakosság bevonását a tervek kidolgozásába.

- Az IVS-ek EU által javasolt stratégiái, céljai: jó minőségü közterek létrehozása, az infrastrukturális hálózatok modernizálása, az energiahatékonyság növelése, a kompakt településszerkezet megóvása, az oktatás, tudáskoncentráció, hálózatépítés programjai, a városrehabilitáció elősegítése, valamint a társadalmi kirekesztés elleni fellépés a városokban (Public Hearing... 2007).

A Lipcsei Charta felhívja a figyelmet a makroszintủ városfejlesztési koncepciók és a területrendezés terveinek szükséges összekapcsolására, a városrészek és a projekt térségeinek (akcióterületek) területi szintủ komplex kezelésére, foglalkozik a központi irányítás és a helyi kezdeményezés szintjeinek kezelésével, vagyis a munkamegosztással a különböző szintek között. Ez a dokumentum nagy figyelmet szentel a város és régiójának kapcsolatára, hangsúlyozva, hogy a város területi integrációja biztonságot ad, segíti a munkamegosztást, erősíti az identitást. Az integrált városfejlesztés céljai között a szociális kérdésekre - ezen belül pedig az anti-szegregációs politikára - megkülönböztetett figyelmet fordítanak. A Lipcsei Charta kiemeli az építési kultúra - a „baukultur” - jelentőségét, amely magában foglalja a minőségi tervezést, az épített örökség megörzését, a modern építészetet és az épités gazdaságosságát. Ez a megkőzelítés új szemléletet jelent: az épített kơrnyezet minősége a városfejlesztési politika meghatározó szempontjává válik (Baukultur... 2007).

$\mathrm{Az}$ EU városfejlesztési politikája jelentős átalakuláson, fejlỏdésen ment keresztül az elmúlt másfél évtizedben. Olyan új elemekkel gazdagodott, amelyekkel a korábbi városfejlesztési stratégiák nem rendelkeztek. Elsősorban a fenntarthatóság szempontjainak meghatározó voltára és az integrált szemlélet kialakulására gondolunk. Véleményünk szerint ez által az EU városfejlesztési politikájában új korszak kezdődött. Az ủj korszak jellemzője az is, hogy európai szintủ gondolkodás indult meg a városfejlesztésben, amelyet hatékonyan támogat a fejlesztési stratégia szempontjainak megfogalmazása és a jelentős uniós támogatási rendszer kidolgozása. Ennek hatása óriási, még akkor is, ha a városfejlesztés a nemzeti politika része maradt.

\section{A fenntartható európai városok Lipcsei Chartájának végrehajtása}

A Lipcsei Charta jelentős elörelépés tehát a városfejlesztésben, de az elveket meg is kell valósítani. 2008 májusában a szlovéniai Brdoban került sor e nehéz feladat megfogalmazására, a vitákra a végrehajtásról, valamint a területi koordinációról. A jó gyakorlatok, hasznos tapasztalatok kicserélése olyan kérdéseket vetett fel, amelyek jelenleg is aktuálisak:

- Egy kézikönyv kidolgozását javasolják, amely az integrált városfejlesztési stratégia szellemében hasznos tanácsokat ad a városfejlesztök számára. (Tehát 
Barta Györgyi: Integrált városfejlesztési stratégia: a városfejlesztés megújitása.

Tér és Társadalom, 23. 2009. 3. 1-12. p.

itt hangzott el elöször a kézikönyv szükségessége, jóval azután, hogy a magyar kézikönyv elkészült, sőt, már a használatára is sor került.)

- Az IVS-ek jogi helyzete tisztázatlan. Ahhoz, hogy betöltsék a fontos szerepüket, az IVS törvényi hátterét is ki kell dolgozni (az IVS-t integrálni kell a területi és településtervezés kialakult rendszerébe).

- A korábbinál nagyobb hangsúlyt kell helyezni a városi társadalmak helyzetének javitására: elsősorban a hátrányos helyzetű városi területek rehabilitációjára, a városi regenerációra, illetve az életkörülmények javítására.

- A Strukturális Alapokat használva kell megvalósítani a fenntartható városfejlesztési projektek operacionalizálását. Az operatív program mint horizontális politika szerepeljen, amelyet fel kell használni a növekedési pólus fejlesztésére, az operatív programban kell továbbfejleszteni az integrált terveket; a rendezési és pénzügyi tervekben pedig jelenjenek meg a stratégiai szempontok.

- A tapasztalatok és információk cseréjéhez területi megfigyelörendszert lenne javasolt kiépíteni; információs egységeket kellene létrehozni; nemzetközi konferenciákat, tanfolyamokat kellene szervezni.

A szlovéniai konferencia javaslatai:

- Szükség van a szektorokat összekapcsoló-átfogó (cross-sectoral) munkacsoportok kialakítására - az integrált megközelítés érdekében.

- Az IVS-ek egyik megoldatlan problémája a városfejlesztés összehangolása, összekapcsolása a térségének fejlesztésével. Ennek koordinálása az operativ programokban még nem eléggé kiforrott.

- Igen nagy probléma a jól képzett tervezők hiánya. Ennek érdekében át kell tekinteni a jelenlegi oktatási rendszert, és azt az igényekhez kell alakítani.

- Az új kihívások felértékelik az építőipar jelentőségét: a klímaváltozás, az energiahatékonyság az építészet számára új feladatokat jelent.

- Rendkívül fontos a jó tapasztalatok kicserélésének folytatása, elsősorban olyan új módszerek elterjesztése, amelyek segítenek a városfejlesztésben részt vevő szereplők kooperációjának, illetve a lakosság bevonásának bővítésében.

- Az EU új tagállamaiban a területi, illetve várostervezés eltérő gyakorlata valósult meg a szocialista időszakban, ezért a várostervezés új szemléletének elsajátítása, a tervezés új gyakorlatának bevezetése ezekben az országokban nagyobb nehézséget jelent. Felvetődött egy átmeneti időszak szükségessége sajátos megoldásokkal.

A szlovén konferencia néhány kérdést nyitva hagyott a további viták számára: melyek legyenek az IVS-ek prioritásai; hogyan alakítható ki a minőségi tervezők elegendô kapacitása; hogyan lehet közelíteni a város- és a régiófejlesztés koordinációját, hogyan lehet kialakítani a fejlesztési tevékenységek többszintúi irányítását, milyen formában lehet megszervezni a rendszeres tapasztalatcseréket? 
Barta Györgyi: Integrált városfejlesztési stratégia: a városfejlesztés megújitása.

Tér és Társadalom, 23. 2009. 3. 1-12. p.

TÉT XXIII. évf. 2009 - $3 \quad$ Integrált városfejlesztési stratégia ... 7

A hosszú elökészület vitáit lezárva, ma már az Európai Bizottság elvárja a tagállamoktól, hogy a Nemzeti Stratégiai Referencia Keretben kiemelten foglalkozzanak a városfejlesztéssel:

- a városok versenyképességének erősítésével, valamint belső strukturális problémáik kezelésével;

- a társadalmi, gazdasági folyamatokat átfogó integrált városfejlesztési koncepció kidolgozásával;

- a városok és környezetük kapcsolatainak erősítésével;

- a helyi szereplők és a lakosság bevonásával a városfejlesztési program készítésébe és megvalósításába;

- többcsatornás finanszírozás megvalósításával (EU, állami központi és önkormányzati, valamint a magánszféra bevonásával).

E szempontok váltak az integrált városfejlesztési stratégiák alapelemeivé.

\section{Eltérö megoldások a városfejlesztésben Nyugat- és Kelet-Európában}

A városfejlesztésnek Nyugat-Európában új kihívásoknak kell megfelelnie. A nyugateurópai városok népessége általában fogy és elöregedik, a bevándorlási hullám elsősorban a nagyvárosok népességének összetételében hozott alapvető változásokat. A gazdasági átalakulás, az ipar kivonulása a városokból új helyzetet teremtett: egyrészt új gazdasági funkciók jelentek meg a városokban (vagy új gazdasági funkciók számára kell vonzó környezetet teremteni), másrészt a kiürült iparterületek helyén létrejött barnamezóket kell valamilyen módon újraintegrálni a városi szövetbe. Nem véletlen tehát, hogy a városok átalakuló társadalmának és gazdaságának kezelése a társadalmi különbségek csökkentése, a szegregációs folyamatok visszafordítása, a belvárosok és a barnamezők rehabilitációja, a környezeti szempontok (klímaváltozás, energiahatékonyság) fokozott figyelembevétele a városépítésben - a terület-, illetve a városfejlesztés eminens feladatává vált. A nyugati világban a városfejlesztés mindig elsösorban helyi feladat, helyi tevékenység volt, jelenleg föleg azt tanulják a városfejlesztők, hogyan lehet a tervezés és megvalósítás folyamatát demokratikusabbá tenni a lokális szereplök szélesebb körének bevonásával, illetve hogyan kell a helyi és a térségi fejlesztés céljait összehangolni. A fejlesztés integrált szemlélete (vagyis az ágazati, területi és időbeli szintek összekapcsolása) szintén új feladatok elé állítják a várostervezöket.

Nyilvánvalóvá vált, hogy a nyugati jóléti rendszerek visszaszorulása, elerỏtlenedése miatt a központi kormányzatok a korábbiakhoz képest kevésbé képesek irányítani, szervezni és finanszírozni a települések fejlesztését, a helyi kezdeményezökészség fokozottabb hasznosítására van szükség a helyi szereplök bevonásával. E folyamat tudatos felismerésében nyújt segítséget az Európai Unió, ösztönözve a tagállami kormányzatokat az IVS átvételére és kiteljesítésére (Cadell-Falk-King 2008; Scott 2008). 
Barta Györgyi: Integrált városfejlesztési stratégia: a városfejlesztés megújitása.

Tér és Társadalom, 23. 2009. 3. 1-12. p.

Az EU újonnan csatlakozott országainak többségében (és itt a kelet-európai volt szocialista országokra gondolunk) - az EU 15-ökhöz képest - más a helyzet. Ezekben az országokban államszocialista berendezkedés határozta meg a korábbiakban a terület- és városfejlesztést, amelyből teljességgel hiányzott a helyi önállóság, így a helyi szintü tervezés és fejlesztés is. A „bottom-up" tervezést tehát most tanuljuk, és az elmúlt két évtized még rövid idő ahhoz, hogy az önkormányzatok, illetve a helyi szereplök és a lakosság felismerje megfelelő módon, hogy nem külső erőktől (központi kormányzat, EU) kell várni helyzetük javítását, hanem helyi összefogással kell megvalósítani céljaikat, illetve kihasználni a külső forrásokat is. Az EU integrált városfejlesztési stratégiảja ezekben az országokban még eröteljesebb változást jelent, mert nemcsak a hiányzó integrált szemléletet kell meggyökeresíteni (átfogóan kell ismerni a város fejlödését, társadalmi-gazdasági struktúráját, és ebbe ágyazva kell kezelni a város gondjait), hanem demokratizálni kell a városfejlesztés folyamatát a helyi erők bevonásával (Lengyel-Rechnitzer 2006; Bajnai 2008)

A helyi kezdeményezőkészség hiánya mellett a várostervezést más problémák is nehezítik a volt szocialista országokban. Súlyos problémák halmozódtak fel városainkban:

- a szocializmus idején túlméretezett és időben elhúzódó iparosítás (fóleg a nehézipar) és annak hirtelen összeomlása okozta - szinte kezelhetetlen - problémák;

- a közel 50 éven át nem létező ingatlanpiac hiányának, illetve a rendszerváltozás utáni zavaros privatizáció káros következményeinek hatása a területhasználatban;

- a környezetszennyezéssel szembeni politikai és társadalmi közömbösség lassú oldódása;

- a rendszerváltozás utáni növekvő szociális különbségek és a felgyorsuló szegregáció a nagyvárosokban;

- a korábban elmaradt fejlesztések (a lakásépítésben és a közlekedés terén);

- a közvetlen helyi források jelentéktelen hányada a települések fenntartásában és fejlesztésében (ami hozzájárul az önkormányzati gazdálkodás hiányzó feltételeihez).

E felhalmozódott problémák megoldását kell az alacsonyabb gazdasági fejlettségü országokban megtalálni, ahol az országok, következésképpen városaik is súlyosabb tökehiánnyal küszködnek, mint a nyugati városok.

A városfejlesztés most új lehetőségekhez jutott: Magyarország egyenrangú tagként élvezheti az Európai Unió megélénkülő városfejlesztési politikájának számára is kedvező hatásait, illetve az ezt alátámasztó jelentős pénzügyi támogatását. Meríthetünk a többi tagállam hasznos tapasztalataiból, jó gyakorlataiból is. Az EU-ban felismerték, hogy az új kelet-európai tagállamok a nyugati partnereikhez képest hátrányos helyzetben vannak, így véleményük szerint is ezekben az országokban átmeneti idöszakra van szükség az integrált városfejlesztés elsajátításában és gyakorlattá válásában. Ebben segít a központi kormányzat, amely az átmenet idöszakában irányítja, átfogja az integrált városfejlesztés folyamatát. Végül is nem ellentmondás, csak éppen nehezebben megvalósítható folyamat a „bottom-up” tervezés erősítése „top-down” segítséggel... 
Barta Györgyi: Integrált városfejlesztési stratégia: a városfejlesztés megújitása.

Tér és Társadalom, 23. 2009. 3. 1-12. p.

\begin{tabular}{lll} 
TÉT XXIII. évf. 2009 — $3 \quad$ Integrált városfejlesztési stratégia ... & 9 \\
\hline
\end{tabular}

\section{Külföldi tapasztalatok}

Érdemes kiemelten kezelni a német városfejlesztési gyakorlatokat, tapasztalatokat. Egyrészt azért, mert a német kormányzat rendkívül nagy figyelmet fordított az Európai Unió városfejlesztéssel kapcsolatos elképzeléseinek kidolgozására, megvalósítására és támogatására - uniós és nemzeti szinten egyaránt.

A városfejlesztéssel kapcsolatos szlovéniai EU DG értekezleten, 2008-ban elhangzott elöadás a német eröfeszitésekröl a Lipcsei Charta végrehajtásával kapcsolatban:

- Tartományi szinteken szerveztünk találkozókat, ahol a Lipcsei Chartát kívántuk népszerủsíteni a városaink számára;

- Programokat szerveztünk az „európai város”, a „,belvảrosok rehabilitációja”, a „Szomszédsági kapcsolatok fejlesztése” témakörökben;

- Rendkívül fontos szempontnak tartjuk az energiahatékonyság növelését, fỏleg a régi és az új lakások energiafogyasztásának racionalizálását. Ennek érdekében a német kormányzat „beruházási egyezséget” hozott létre 2008-ban;

- Ugyancsak fontos iránynak tartjuk a „baukultur” erősítését, amely a városfejlesztési politikánk alapjává vált.

- Az eredetileg közös szövetségi-tartományi finanszírozású Szociális város programot (Soziale Stadt) forrásoldalról tovább bővítettük. Így kiegészítettük egy EU-s, ESZA finanszírozású programmal (BIWAQ), amely 2008-tól finanszírozza a lakosság tanulását, a képzettség javítása érdekében, erősíti a munkaerőpiac perspektíváit. Ez a program támogatja az új oktatási és foglalkoztatási kezdeményezéseket, a közösségi részvételt, figyelemmel van a nők és a bevándorlók helyzetének javítására.

Másrészt, érdekes tapasztalatokra tehetünk szert a német terület- és városfejlesztés tanulmányozásakor. Németországban, a korábbi tradíciók (föleg a szövetségi rendszerből következően) és még inkább az eltérő nyugat- és kelet-német helyzet, gyakorlat következtében együtt jelent meg a „top-down” és a „bottom-up” városfejlesztési politika.

Kétségtelen, hogy Magyarország és Németország államberendezkedése eltéro, ám a tervezés mindkét államban erőteljesen központilag irányított. A 2007-2013 tervperiódusban Németország keleti részét és Magyarország egészét az EU jelentős forrásokkal támogatja. Miközben a városok - föleg a nyugati országrészben - fejlesztési gyakorlatukat modernizálják az integrált politikáikban, addig a kelet-német városok majdnem ugyanúgy tanulják a helyi kezdeményezésủ városfejlesztést (az EU és a kormányzati ösztönzők éppen olyan „motor” szerepet töltenek be ezekben a városfejlesztési programokban), mint a kelet-európai város-társaik („csupán” lényegesen több anyagi forrást képesek mozgósítani). A sajátos német politika tanulmányozása kétszeresen is hasznos a számunkra: megismerhetjük a városi kezdeményezések technikáit, és a központi kormányzati irányítás módszereit a városfejlesztésben.

Czirfusz Mártonnak a németországi városfejlesztési gyakorlatról szóló cikke (Czirfusz 2009) a brandenburgi felsőfokú központok integrált városfejlesztési stratégiáin keresztül a „kőzponti hely elméletnek” és a „,növekedési pólus elméletnek” 
Barta Györgyi: Integrált városfejlesztési stratégia: a városfejlesztés megújitása.

Tér és Társadalom, 23. 2009. 3. 1-12. p.

együttes megjelenését mutatja be a gyakorlati városfejlesztésben. A két elmélet alkalmazása a terület- és városfejlesztésben nyilvánvalóan ellentétes célok megfogalmazását feltételezi, ezért együttes megjelenésük ellentmondásos: a központi hely elmélet alkalmazása a területfejlesztésben a térbeli kiegyenlítódést segíti a lakosság ellátásában, míg a növekedési pólus elmélet a város adottságainak fejlesztésével kívánja a település versenyhelyzetét növelni. A kétféle megközelítés - kiváltképpen a brandenburgi gyakorlatban - egyrészt a központi tervezés ma is jelentős szerepére, másrészt (talán) a tervezők (magyarországihoz hasonló) sajátos, nevezetesen a szocializmusból örökölt gondolkodásmódjára is utal.

Földi Zsuzsa tanulmánya (2009) kritikai realista keretbe ágyazva mutatja be az európai és hazai tapasztalatokat a városfejlesztésben megjelenő társadalmi részvételről. Az országok történelmének, demokratikus hagyományainak és nemzeti politikáinak sajátosságai miatt az az igény, hogy a helyi társadalom is részt vehessen, sőt, dönthessen a helyi ügyek tervezésében, fejlesztésében és megvalósitásában igen eltérő megoldásokat hozott a nyugat-európai városfejlesztésben. Mindemellett, a hosszú időre visszatekintő, alapvetően demokratikus berendezkedésnek köszönhetően a nyugat-európai országokban egyáltalán nem idegen elem a társadalmi részvétel. Ezekben az országokban a társadalmi részvétel különböző szintjei alakultak ki: a legalsó szintet a lakosság információval való ellátása jelenti, második szinten a lakosság már kinyilváníthatja kritikai észrevételeit, de a döntéshozásba nincs beleszólása, míg a felső szinten a lakosság valóban részt vesz a döntéshozásban, így nem csak befolyásolja, de részben irányítja is a fejlesztés végső kimenetelét. Földi Zsuzsa cikkének izgalmas eleme a nemzetközi tapasztalatok összehasonlítása a magyar gyakorlattal. Kritikai szemléletével rámutat a társadalmi részvétel nálunk akadozó mủködésének főbb okaira. A már a gyakorlatban is kipróbált nemzetközi módszerek megismerése és felhasználása is segíthet abban a türelmes munkában, amely egyrészt kényszeriti a döntéshozók szük körét a demokratikus szemlélet átvételére, másrészt felkelti a helyi lakosság érdeklődését saját ügyeik intézése iránt.

\section{Jegyzetek}

${ }^{1}$ Javaslatok az integrált városfejlesztési stratégiák készitését segitő Kézikönyv módosítására hazai IVS-ek elemzése és külföldi tapasztalatok alapján c. kutatás eredményeit használva. Az MTA RKK Budapesti Osztályát a Nemzeti Fejlesztési és Gazdasági Minisztérium bízta meg 2008-ban e feladattal (témavezetỏ Barta Györgyi).

2 Például, 2009 januárjában és márciusában a Magyar Urbanisztikai Társaság, februárban a Budapest Kör rendezett érdekes vitákat az IVS-sel kapcsolatban.

3 2009-2010 után már nem hirdetnek meg új pályázatokat.

${ }^{4}$ Cselekvési munkaprogram - Lille-i konferencia (2000), városfejlesztési joganyag - Rotterdam Konferencia (2004), Bristoli megállapodás a fenntartható városi közösségekről (2005), Bizottsági közlemény a 2007-2013 közötti idószakra vonatkozó közösségi stratégiai iránymutatásokról (2006), Bizottsági kommunikáció a kohéziós politika városi vonatkozásairól (2006), az EU Területi programja (Területi Agenda, 2007) - az integrált megközelítésről, Európai Épitészetpolitikai Fórum - az építési kultúra a fenntartható városfejlesztésért (2007). 
Barta Györgyi: Integrált városfejlesztési stratégia: a városfejlesztés megújitása.

Tér és Társadalom, 23. 2009. 3. 1-12. p.

TÉT XXIII. évf. 2009 - 3

Integrált városfejlesztési stratégia ... 11

\section{Irodalom}

Bajnai L. (2008) Városfejlesztés. Scolar, Budapest.

Barta Gy. témavezető (2008) Javaslatok az Integrált Városfejlesztési Stratégiák készitését segitōo Kézikönyv módositására hazai IVS-ek elemzése és külföldi tapasztalatok alapján. MTA RKK Budapesti Osztály, Budapest.

Baukultur as an impulse for growth good examples for European cities. (2007) Selected case studies. Ministry of Transport, Building and Urban Affairs, Centre for Public Space Research, BerlinCopenhagen.

Brenner J. (2007) Európai városaink jövője - városfejlesztés és építési kultúra. - Magyar Szemle. 9-10. Online.

Cadell, Ch.-Falk, N.-King, F. (2008) Regeneration in European cities: making connections. Joseph Rowntree Foundation, York.

Czirfusz M. (2009) Ellentmondásban? Központi helyek elmélete és a városok specializációja. - Tér és Társadalom. 3. 13-25. o.

Egységes tervezési rendszer szakértői elókészitése. (2006) Terra Studio Kft., Budapest.

European Common Indicators. (2003) Towards a Local Sustainability Profile. AMBIENTE ITALIA, Instituto de Recerche, Milano.

Földi Zs. (2009) A társadalmi részvétel szerepe a városfejlesztés gyakorlatában - európai és hazai tapasztalatok. - Tér és Társadalom. 3.27-43. o.

From Charter to Commitments. (2004) Inspiring futures for local governments in progress. The Aalborg+10conference „Inspiring Futures". http://www.aalborgplus $10 . \mathrm{dk} /$ media/chartercommitment.pdf

Integrated Urban Development - a Prerequisite for Urban Sustainability in Europe. (2007) Background Study on the "Leipzig Charter on sustanaible European cities” of the German EU Council Presidency. Bundesinstitut für Bau-, Stadt- und Raumforschung (BBSR) http://www.bbsr.bund.de (cln_016/nn_26160/BBSR/EN/Publications/OnlinePublications/2007/DL_EU_09_07,templteld=ra w,property-publicationFile.pdf/DL EU 09 07.pdf

Kézikönyv a városok számára. Városrehabilitáció 2007-2013-ban. (2007) Önkormányzati és Területfejlesztési Minisztérium, Budapest.

Lengyel I.-Rechnitzer J. (2006) Kihivások és válaszok. A magyar épitöipari vállalkozások lehetöségei az EU-s csatlakozás utáni idöszakban. NOVADAT, Györ. http://www.eco.u-szeged.hu/ region_gazdfejl_szes/konyv $7 . \mathrm{html}$

"Pre-Regeneration" hazai városok felkészülése az integrált városfejlesztési módszertan elsajátitására. (2005) Városháza, Miskolc.

Public Hearing on Territorial Agenda and Leipzig Charter. (2007) EP Press Service, Brussels. http://www.eroperl.europa.eu/document/activities/cont/200805/20080530ATT30415/20080530ATT30 415EN.pdf

Scott, A.J. (2008) Resurgent Metropolis: Economy, Society and Urbanization in an Interconnected World. - International Journal of Urban and Regional Research. 3. 548-564. o.

The Territorial State and Perspectives of the European Union Document - Towards a Stronger European Territorial Cohesion in the Light of the Lisbon and Gothenburg Agenda. (2006) European Urban Knowledge Network. http://www.eukn.org/binaries/eukn/news/2006/8/territorial-agenda-14-aug.pdf

Városfejlesztési Kézikönyv. (2009) 2. javított kiadás. Nemzeti Fejlesztési és Gazdasági Minisztérium, Budapest. 
Barta Györgyi: Integrált városfejlesztési stratégia: a városfejlesztés megújitása.

Tér és Társadalom, 23. 2009. 3. 1-12. p.

\section{INTEGRATED URBAN DEVELOPMENT STRATEGY: RENEWAL OF URBAN DEVELOPMENT}

\section{GYÖRGYI BARTA}

The integrated urban development strategy (IUS) was strongly endorsed by the Leipzig Charta (2007). This approach to urban development includes social, economic and regional aspects and tries to incorporate the various local levels and contextual time lines, involving local actors into the planning process, while looking for financing to both government and private sources. Although IUS requires new and hitherto unknown efforts from many Western European countries and cities, particulary in the process of civic participation, it opens a fundamentally new era in the ex-socialist member countries of the European Union. In spite of the fact that more than a hundred IUS blueprints have already been elaborated by Hungarian municipalities, there is a general realisation that the desired renewal of Hungarian urban development is still to be found. To know and use some of the sophisticated methods filtered out by way of comparative international studies may assist in this long and difficult procedure. In this contribution, the introductory section about the historical development of IUS within the EU is followed by two studies illustrating British, Dutch and German best practices in urban development. 